\title{
FINANCING SMES - PROSPECTS IN HUNGARY
}

\author{
(1) Mester Éva, (2) Tóth Róbert \\ (1) University of Science at Szeged, Economic Doctor School, Gránit Bank Zrt., Business \\ Branch, deputy managing director, \\ (2) Szent István University, Faculty of Economy and Social Sciences, Finance MSc, student
}

\begin{abstract}
After joining the EU, micro, small and medium enterprises came to the focus of attention in Hungary for their grandiose role in both employment and producing added value. Due to their flexibility, creativity and adaptability SMEs find new market opportunities easier. Also, SMEs can find their way and seize appearing opportunities more quickly under rapidly changing, insecure and high-risk circumstances.

When analysing the sector, besides the investigation of the external environment, it is also important to focus on internal factors. The success of businesses is not only influenced by their access to financial resources, but also by their internal organisational structure and the standard of their organisational culture. In the present phase of world economy, when transports are delayed, credits are harder to obtain and companies downsize, leaders have to make careful and considerate management and operational decisions. Thus financial decisions have considerable short and long-term effects on the success of business operation.
\end{abstract}

This research paper aims at a comprehensive study of the present situation of the Hungarian SME sector, some of its financing opportunities, as well as factors that hinder its development. Another purpose of the present writing is to lay the theoretical foundations for questionnaire primary research exploring the financing characteristics of SMEs in Hungary.

Keywords: small and medium enterprise, competitiveness, financing JEL classification: $G 3$

\section{Introduction, the timeliness and complexity of the topic}

In Hungary the concept of small and medium enterprises (SMEs) is defined by the Act XXXIV of 2004. Thereby those enterprises belong to this category, where the number of employees is maximum 249, the annual net sales revenue does not exceed 50 million euros, or the balance sheet total does not exceed 43 million euros, and the capital or voting rights share the state or any local self-government holds, either directly or indirectly and either solely or jointly, does not exceed 25\% (Szerb, 2008). The statistical limits are based on headcount categorisation. Pursuant to this categorisation, entities with a number of employees no more than 49 qualify as small enterprises - within this category are micro enterprises with a headcount of less than 10 -, whereas enterprises with a headcount of 50-249 are regarded as medium-size. In Hungary the enterprise sector is dominated by micro, small and medium-size enterprises, the micro enterprise prevailing. The economic status of SMEs has increased, which is mainly caused by corporations outsourcing tasks in order to cut costs. The majority of suppliers are smaller and more flexible enterprises. These companies can identify market opportunities quickly and are quick to react to changes. For doing so there is a need for enhanced efficiency and the development of an adequate strategy, i.e. their success requires an existing management (Gyenge, Buresch and Kozma, 2013). Although SMEs started out in the local economy, more 
precisely in the retail service sector, recently they have appeared in the field of innovative business services. These are mainly network-based enterprises entering the global market. The SME sector plays an important role in the production of the state's income, in foreign working capital, in investment, and, from a social point of view, in job creation and employment.

\section{Material and Methods}

The aim of this study is to show, based on secondary sources, the role small and medium companies play in Hungary's economy and socio-political target system at present. The study includes a thorough analysis of academic sources, through which practical processes are examined. This study is the first step in an ongoing research project, serving as a basis for a primary research whose aim is to explore the current financing situation and problems of micro, small and medium enterprises in Hungary.

\section{SMEs in Hungary}

In Hungary SMEs constitute the bulk - 99.8\% - of active enterprises. The SME sector plays an important economic role in the production of the state's income, in foreign working capital, in investment, and, from a social point of view, in job creation and employment. Following the Recession of 2008 the Hungarian SME sector could not gain strength. From 2009 to the end of 2012 the branch was lacking in force, however, since 2013 there has been a slight growth. The SME sector was hit worse by the recession than large enterprises. The headcounts in the SME sector is about level with the 2008 numbers. SMEs provide jobs for about 2 million Hungarians, amounting to $73 \%$ of overall employment. The number of staff employed in the sector had seen a dynamic increase in the 1990s, after the millennium this tendency slowed down and in fact it halted, thus SMEs could not exert a stabilising effect on employment.

Figure 1. shows the change in the number of registered and active enterprises in Hungary between 2008 and 2012. It is apparent that active enterprises account for the half of actually registered enterprises. Numerically, it means that in 20051.208 .780 , whereas in 20131.688 .169 enterprises were registered in Hungary, which translates to $40 \%$ increase. However, the number of actually active enterprises was 707.756 in 2005 and 656.458 in 2012. After the year following the Great Recession figures show a decreasing tendency. Thus, there is significant difference between the two categories, as shown in the figures below.

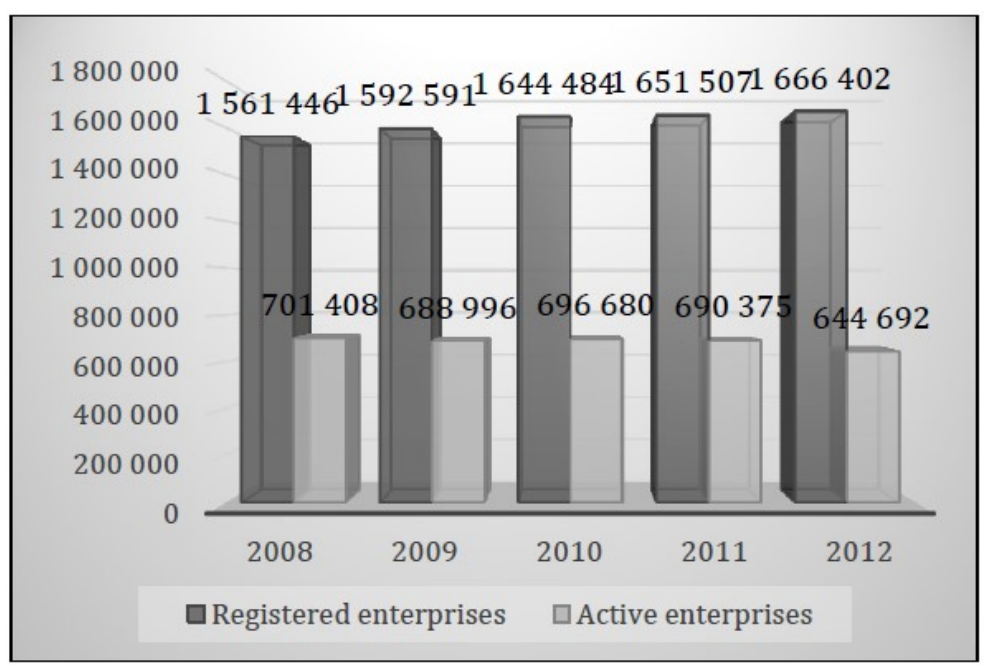

Figure 1. The number of registered and active entereprises

Source: http://www.ksh.hu/docs/hun/xstadat/xstadat_eves/i_qpg001.html [2 April 2015] 
Table 1. The number of active enterprises per region

\begin{tabular}{|l|l|l|l|l|l|l|l|l|}
\hline & $\mathbf{2 0 0 5}$ & $\mathbf{2 0 0 6}$ & $\mathbf{2 0 0 7}$ & $\mathbf{2 0 0 8}$ & $\mathbf{2 0 0 9}$ & $\mathbf{2 0 1 0}$ & $\mathbf{2 0 1 1}$ & $\mathbf{2 0 1 2}$ \\
\hline $\begin{array}{l}\text { Central } \\
\text { Hungary }\end{array}$ & 273283 & 271965 & 270786 & 277680 & 274673 & 279430 & 279916 & 264486 \\
\hline $\begin{array}{l}\text { Central } \\
\text { Transdanubia }\end{array}$ & 73886 & 72161 & 71177 & 71403 & 69703 & 70153 & 69077 & 63504 \\
\hline $\begin{array}{l}\text { Western } \\
\text { Transdanubia }\end{array}$ & 70597 & 69592 & 68820 & 69457 & 68409 & 69034 & 68111 & 62221 \\
\hline $\begin{array}{l}\text { Southern } \\
\text { Transdanubia }\end{array}$ & 61686 & 60432 & 58878 & 59825 & 58644 & 59352 & 58077 & 53558 \\
\hline $\begin{array}{l}\text { Northern } \\
\text { Hungary }\end{array}$ & 63306 & 61696 & 60703 & 61091 & 59461 & 59280 & 58234 & 54081 \\
\hline $\begin{array}{l}\text { Northern } \\
\text { Great Plain }\end{array}$ & 82696 & 81515 & 78942 & 81170 & 79446 & 80067 & 78868 & 73760 \\
\hline $\begin{array}{l}\text { Southern } \\
\text { Great Plain }\end{array}$ & 82302 & 80785 & 78752 & 80782 & 78660 & 79364 & 78092 & 73082 \\
\hline Total & $\mathbf{7 0 7} \mathbf{7 5 6}$ & $\mathbf{6 9 8} \mathbf{1 4 6}$ & $\mathbf{6 8 8} \mathbf{0 5 8}$ & $\mathbf{7 0 1} \mathbf{4 0 8}$ & $\mathbf{6 8 8} \mathbf{9 9 6}$ & $\mathbf{6 9 6} \mathbf{6 8 0}$ & $\mathbf{6 9 0 3 7 5}$ & $\mathbf{6 4 4} \mathbf{6 9 2}$ \\
\hline
\end{tabular}

Source: https://www.ksh.hu/docs/hun/xstadat/xstadat_eves/i_qvd004b.html [2 April 2015]

Table 1. shows the distribution of active enterprises between 2005 and 2012 in Hungarian regions. The sector is substantially determined by regional concentration as shown by the fact that $41 \%$ of active SMEs - 4 out of 10 - is concentrated in Central Hungary. The other regions contribute at similar rates.

Figure 2. shows the distribution of active enterprises in different branches of economy. The SME sector in Hungary is dominated by the service industry (approximately $80 \%$ ) . Most of them -133.866 , making up $21 \%$ of all enterprises - operate in trade.

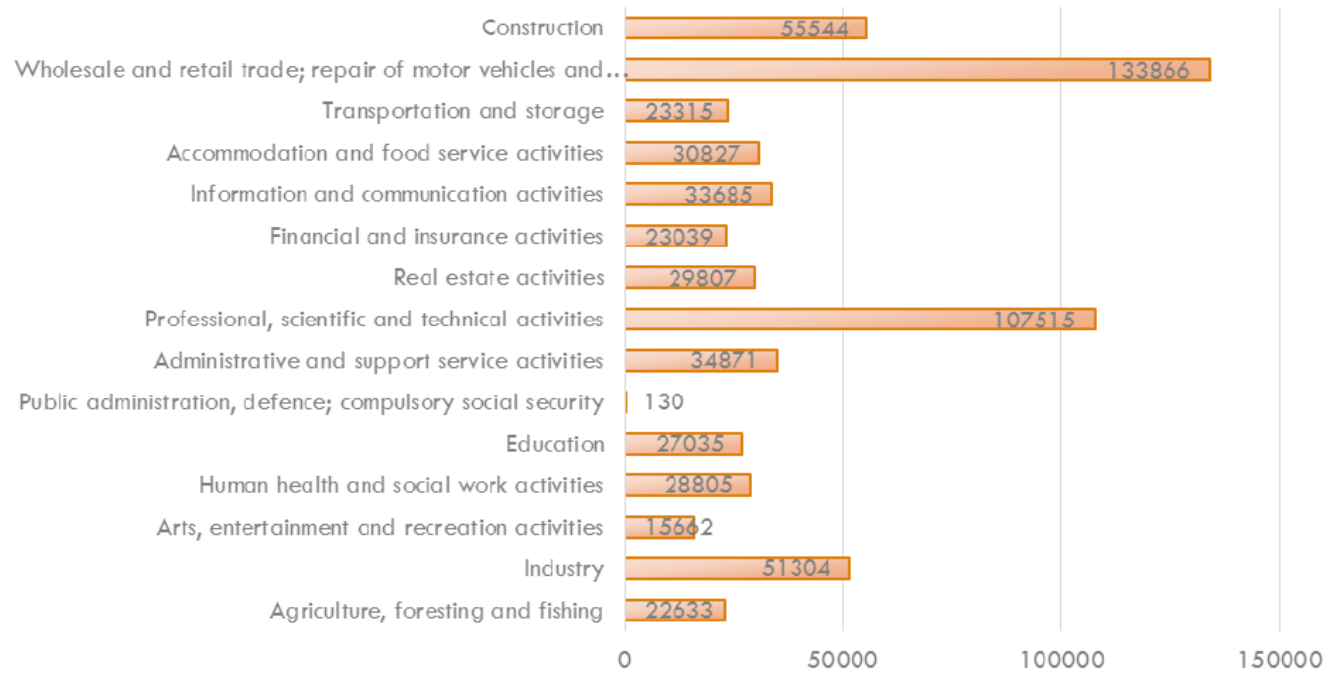

Figure 2. The number of active enterprises per economic branches (2012)

Source: http://www.ksh.hu/docs/hun/xstadat/xstadat_eves/i_qpg008.html [02 April 2015]

Under the heading Industry I categorised manufacturing, food, mining, pharmaceutical industry, chemical industry, textile, wearing apparel, leather, and leather goods industry, making up altogether $8 \%$ of active enterprises. Construction is highlighted as a separate heading, since it operated 55.544 enterprises in 2012, surpassing the aforementioned 'industry'. Together they account for $16.6 \%$ of the total number. Enterprises engaged in professional, 
scientific and technical activities are also worth mentioning, for, in 2012, more than 107 thousand enterprises were operated in these areas. These enterprises pursue their activities based on substantial knowledge, moreover, they are the ones capable of undertaking innovative activities. Innovation plays (should play) an important role in national economy since at present those countries are able to grow which compete with their innovation, research and development, ultimately, using knowledge. In Hungary this trend is not prevailing (Kállay, Kissné, Köhegyi and Maszlag, 2005). Hungary can be regarded as an 'assembler' country due to the operation of car factories, which cannot serve as a basis for permanent growth and longterm competitiveness.

\section{The role of SMEs in employment and economy}

SMEs' significance in economic policy is mainly due to their importance in employment. It is highlighted by the fact that they contribute considerably to employment: $71.4 \%$ of Hungarian employees work for SMEs [NEMZETGAZDASÁGI MINISZTÉRIUM,]. This fact is underlined by the idea appearing in multiple articles of Organisation for Economic Cooperation and Development (OECD) saying "small enterprises are the most important sources of innovation, growth and job creation" (OECD Economic Surveys Hungary, 2014). Therefore, a heavier emphasis should be placed on the enterprise sector, and more specifically on SMEs as major job creating forces (Kállay, 2012). Measures undertaken by the government are needed as results can only be attained by the co-operation of the $3 \mathrm{Ks}$, the government, the central bank and the SMEs (the 3 'Ks' refer to the Hungarian name for the three partners). The classification of enterprises is usually based on headcounts (Béza and Csubák, 2005). In Hungary the number of enterprises in the size-categories between 2006 and 2012 was as follows.

Each size-category based on headcounts is dominated by micro enterprises employing maximum 9 people in every region. The ratio of bigger companies only reaches $5 \%$ in Central Hungary and the Southern Great Plain. SMEs mainly provide services, which has an influence on their efficiency, and their capacities in investment and employment. In 2012 there were altogether 28 thousand SMEs operating on foreign capital in Hungary. Regional concentration is even more significant among them: $70 \%$ of them work in Central Hungary, and two thirds of foreign capital investment is also concentrated here.

The SME sector is one of the most important contributors of Hungarian economy. As can be seen from the previous section, they play a vital part in employment, besides, have a major role in economic performance. It is underlined by data from the Hungarian Central Statistical Office (HCSO) showing that SMEs produced 54\% of GDP in 2007, 55\% in 2009 and 56\% in 2011. Therefore, it can be seen that SMEs produce the half of the GDP with micro, small and medium enterprises contributing in the same proportion. According to 2014 November data from the HCSO, in 2012 SMEs produced almost 45 billion HUF turnover, which is 58\% of the output in the whole of the entrepreneurial sector. Compared with 2011 data, SMEs' income increased in every region, with the exception of Northern Hungary and Southern Transdanubia. Enterprises produced 70 million HUF on average, which increased in direct proportion with their size. Although their turnover exceeded the 2011 results, they spent less on investment. In 2012 the scale of investments reached 1450 billion HUF, which accounts for $46 \%$ of investments in the enterprise sector. Except for Central Hungary, SMEs centred their investments in three branches: industry, agriculture and trade. 


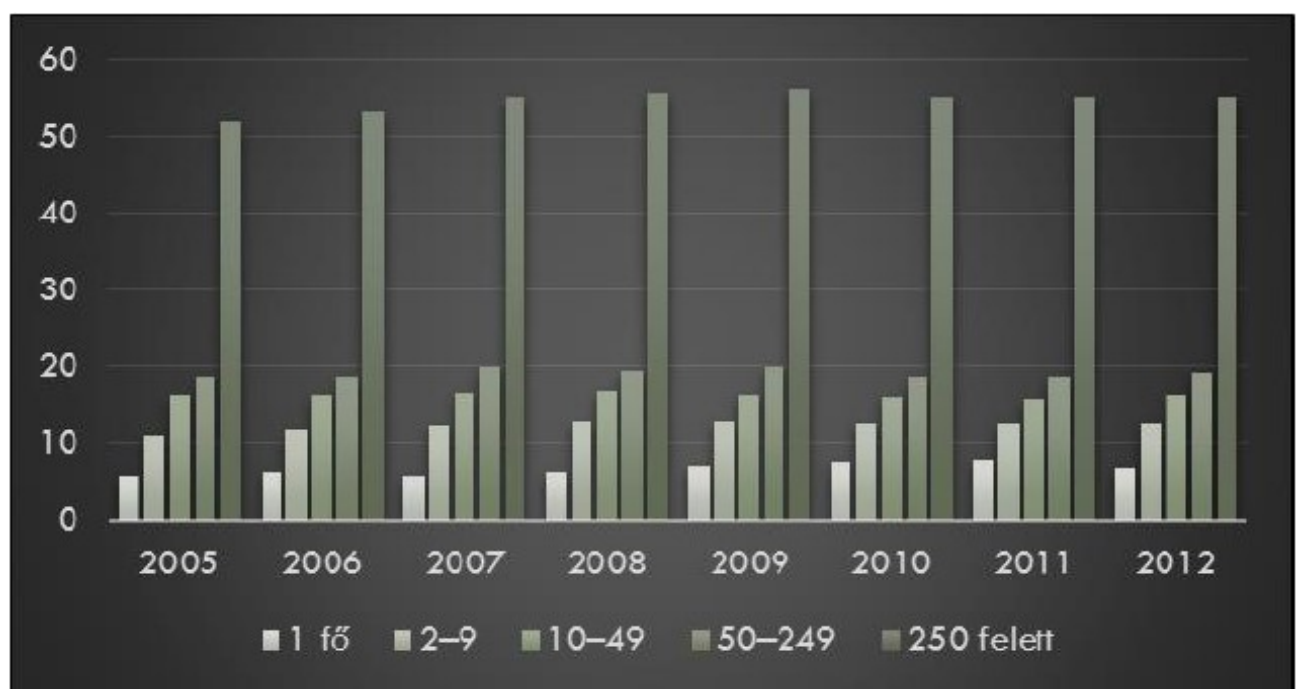

Figure 3.: GDP contribution per size-category

Source: A kis- és középvállalkozások helyzete Magyarországon, KKV Évkönyv 2012, Budapest, 2012

Figure 3. shows GDP contribution per size-category. It is established that in the time interval in question there was no significant change in the production of gross value added (GVA). GDP contribution also rises in proportion with the increase in company size. SMEs' GDP contribution has not decreased since the recession, a minimal increase can be realised. Even a stagnant contribution could be viewed as exceptional under such turbulent economic conditions. However, the situation dramatically changes if we consider that more than $70 \%$ of the employment is concentrated in this sector. Based on branch distribution $60 \%$ of the GDP was produced in the service sector. Trade plays a less dominant role with only $18-20 \%$ of SMEs' economic performance in 2012 . SMEs share in enterprise generated revenues surpassed $60 \%$ between 2001 and 2010, with the exception of two years. Since 2011 this value has slightly decreased, in 2012 the total turnover produced by small and medium companies being just above 58\%. When discussing SMEs' economic power their role in export has to be taken into consideration as well: they make up one third of export (Walter, 2014).

\section{Hungarian SMEs in international comparison}

SMEs play an important role not only in Hungary, but also in the European economy. More than 20 million SMEs are operated in the EU employing 87 million people. It has to be emphasised that in certain branches, such as construction, textile and furniture industries, and today logistics have to be included as well, employment rate reaches or even exceeds $80 \%$ [EUROPEAN COMISSION, 2014]. In 28 EU countries the majority - 93\% - of enterprises is a micro company, making up 30\% of employment and producing $17 \%$ of turnover (Table 2.). In contrast, large companies represent only $0.2 \%$ of enterprises, with $33 \%$ in employment and $44 \%$ in turnover. In 2011, in every EU member state, a significant number of companies belonged to micro-sized enterprises. Small and medium-sized companies were represented at the highest rate in Germany (18\%), Romania, Luxemburg (13\%) and Austria (12\%), whereas the fewest number were in Slovakia (4\%). Large companies make up at about $0.5 \%$ in each member state. SMEs contributed $5 \%$ on average to the gross value added at factor cost produced by European enterprises, which is 4 percentage point more than in Hungary. In terms of employment we can talk about a reverse process, in Europe SMEs averaging at $67 \%$, while the number being above seven-tenth in Hungary. 
Table 2. Distribution of small and medium enterprises based on categories

\begin{tabular}{|l|c|c|c|c|c|c|}
\hline & $\begin{array}{c}\text { Micro } \\
\text { enterprise }\end{array}$ & $\begin{array}{c}\text { Small } \\
\text { enterpris } \\
\text { e }\end{array}$ & $\begin{array}{c}\text { Medium } \\
\text { enterpris } \\
\text { e }\end{array}$ & $\sum$ SMEs & $\begin{array}{c}\text { Large } \\
\text { enterpris } \\
\text { e }\end{array}$ & $\begin{array}{c}\sum \\
\text { Enterprise } \\
\text { s }\end{array}$ \\
\hline $\begin{array}{l}\text { Number of } \\
\text { enterprises } \\
\text { (units) }\end{array}$ & $19,969,338$ & $1,378,374$ & 223,648 & $21,571,36$ \\
0 & 43,517 & $21,614,908$ \\
\hline $\begin{array}{l}\text { Rate of } \\
\text { enterprises (\%) }\end{array}$ & $92.4 \%$ & $6.4 \%$ & $1.0 \%$ & $99.8 \%$ & $0.2 \%$ & $100 \%$ \\
\hline $\begin{array}{l}\text { Number of } \\
\text { employees } \\
\text { (capita) }\end{array}$ & $38,629,012$ & $27,353,66$ & $22,860,79$ & $88,843,46$ & $44,053,57$ & 6 \\
\hline $\begin{array}{l}\text { Rate of } \\
\text { employment } \\
\text { (\%) }\end{array}$ & $29.1 \%$ & $20.6 \%$ & $17.2 \%$ & $66.9 \%$ & $33.1 \%$ & $100 \%$ \\
\hline GDP (\%) & $21.6 \%$ & $18.2 \%$ & $18.3 \%$ & $58.1 \%$ & $41.9 \%$ & $100 \%$ \\
\hline
\end{tabular}

Source: Eurostat, National Statistical Offices and DIW Econ [02 April 2015]

Taking turnover, gross added value and employment into consideration, small and medium enterprises play the biggest role in Estonia, while their significance is the lowest in the UK comparing countries that have reported data. If we compare Hungary with neighbouring countries, SMEs's contribution to GVA is higher in four of them. Considering employment, SMEs play at about the same or even more important role in Slovakia and Slovenia, but much less in Romania.

In 2011, the majority of SMEs were micro companies employing maximum 9 people in all member states in question, the number of companies with minimum 10 people approached or exceeded $10 \%$ in 7 countries (the three Baltic countries, Austria, the UK, Luxemburg and Romania). The latter number was 5.1\% in Hungary, which was the 5th least among reporting countries and significantly less than the EU-28 average, $7.3 \%$.

To sum up, the management of Hungarian SMEs is characterised by high employment but low capital-intensity, but the greatest problem is effectiveness. In Hungary employment is significantly higher in micro enterprises, whereas it is smaller in large companies. In EU-27 countries SMEs contribute more to GVA, while large companies contribute the same amount less. The biggest difference appears in productivity: in EU-27 countries average productivity is three times higher than in Hungary. Productivity gap is the highest for micro enterprises and the lowest for large enterprises. Similar to the international trend, in the Hungarian SME sector, the size of businesses is positively correlated to every major indicator of competitiveness, large businesses have a higher capital-intensity, their employees and leaders are more highly qualified, they generate innovation more often, spend more on research-development, have better access to sources of financing and show better specific result indicators. Therefore, the future development of the Hungarian SME sector requires the transformation of the sizestructure and the growth of average business size. Given a stable regulatory environment, an effective application of direct investment and employment incentive, the chances for growth are the highest in the SME sector if businesses are subsidised by both capital market and bank financing schemes with adequate state participation in an adequate regulatory environment. 


\section{Main financing source for the small and medium-sized enterprises}

In spite of the fact that the small and medium-sized enterprises play important role in every national economy, the must face several hardships. The most serious problems are the lack of capital and the access to financing sources. In this chapter of our study we analyse this problems and turn the attention to some possible solutions. Our paper is forerunner of an actual research work presenting some expectable results. Following a group of questions concerning the basic data of the company (size, branch, economical data, structure of ownership, etc), the primary survey research discovering the financial characteristics of the Hungarian small and mediumsize enterprises gathers data from the companies concerning the financing experiences and touches upon the objective and subjective assessment of the Growth Credit Program from the point of view of the companies as well. The external sources are grouped into forms shown in Figure 4.

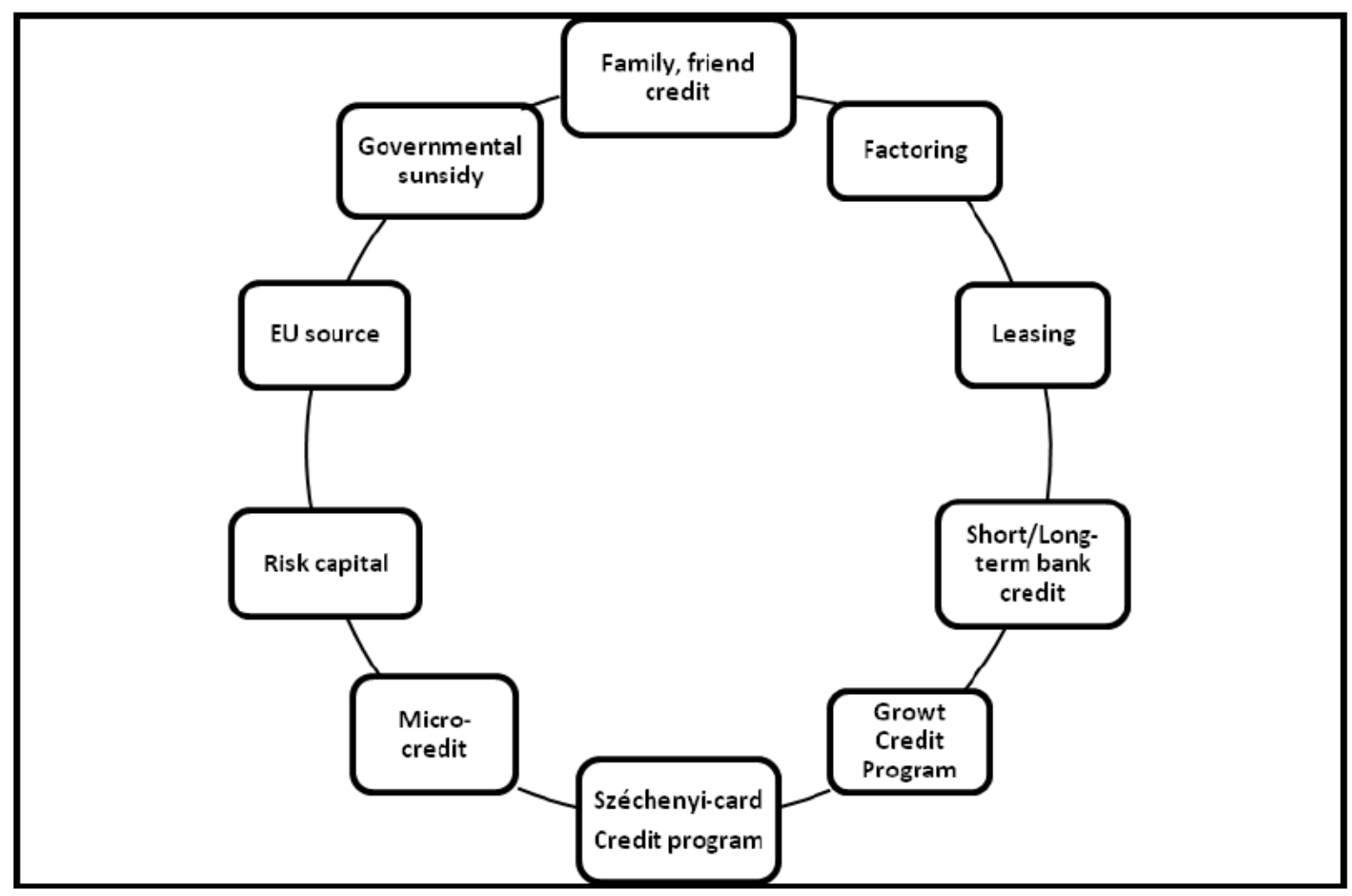

Figure 4. Grouping the external financial sources

Source: own edition, 2015

From among the external sources, the small and medium-sized enterprises may obtain government supported external subsidies in the form of non-reimbursable subsidies, credits and - in certain cases - warranties. We do not want to forecast the results of the survey, but it seems to be reasonable that among the external sources the dominance of the bank-credits in the analyses of the respondents will not change, if the goal is the enhancement of efficiency. The finance related decisions shall aim at the finding of sources required to the maintenance of the continuous liquidity and solvency to minimise the company's weighted capital costs and the harmonisation of the maturity structures of the assets and sources, i. e. short-term liabilities should face short-term sources and the long-term investments should be implemented from long-term sources. Among others, the obtainable balance sheet earnings, the company's ability to pay dividend, the capital structure, the need of foreign sourcing, the often paid corporation 
tax and the probability of bankruptcy depend on the company's financial policy [Csubák K, 2003]. The chapter of the SBA-information bulletin (2014) dealing with the access of the Hungarian small and medium-sized enterprises to financial sources paints an interesting picture. Concerning the access to financial sources by small and medium-sized enterprises, Hungary's performance corresponds to the union's average (Figure 5.). However, concerning the majority of the individual parameters, Hungary failed to make improvements. The relatively better position beyond the union's average is only due to the significant deterioration of the financing in the other member states and partly to the concrete constructions of financing initiated by the bank of issue. The availability of the Széchenyi Card Program and the risk-capital supporting the financing of the small and medium-sized enterprises had a stimulating effect as well. In spite of this fact, the financial position of the most small and medium-sized enterprises is wrong in the future too. As in many member states of the union, the access to financial sources depends always on the specific manner of financing. The access to bank-credits was improved gradually, but it became more expensive at the same time. While the difference between the interest rates between the small credits - below EUR 1 million - intended mainly for the small and mediumsized enterprises and the higher ones is lower than in other member states, this overcharge was increased from 12\% in 2007 to almost 19\% in 2013. Furthermore, the lower credit overcharge involves advantages for the small and medium-sized enterprises being able to access to credits only. The rate of the refused credit applications, however, is higher in Hungary than in other member states in spite of the fact that it was decreased from $26 \%$ in 2012 to $17 \%$ in $2013.28 \%$ of the Hungarian small and medium-sized enterprises have reported lower willingness of the banks to credit (in case of the EU this rate was $28 \%$ ). A forceful intervention of the government has alleviated this problem to some degree. Thanks to the government's move, at the beginning of the crisis, the proportion of the small and medium-sized enterprises experiencing difficult access to publicly financed subsidies, among others to warranties, was decreased from $31 \%$ in 2008 to $21 \%$ in 2013 . The other parameters remained more or less unchanged. The Hungarian enterprises receive payments earlier than their counterparts in the union (42 days as compared to 50 days), while the proportion of the overdue payments (4\%) almost equals to the union's average. In fact, concerning the cash-flow, the position of the Hungarian small and mediumsized enterprises is much worse than the counterparts' situation in the union.

Deviation from the EU average (expressed in deviation. $E U$-average $=0$ )

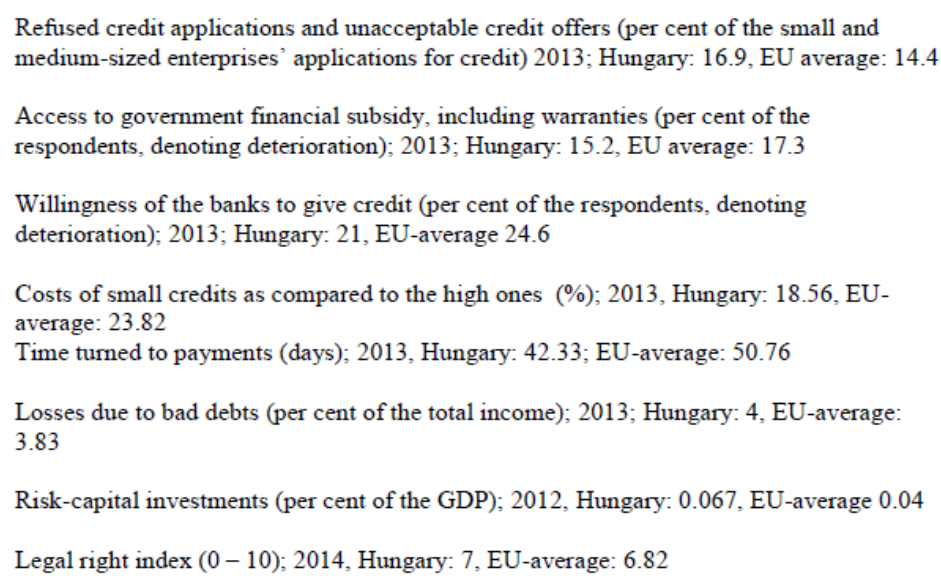

Refused credit applications and unacceptable credit offers (per cent of the small and medium-sized enterprises' applications for credit) 2013; Hungary: 16.9, EU average: 14.4

Access to government financial subsidy, including warranties (per cent of the respondents, denoting deterioration); 2013; Hungary: 15.2, EU average: 17.3

Willingness of the banks to give credit (per cent of the respondents, denoting deterioration); 2013; Hungary: 21, EU-average 24.6

Costs of small credits as compared to the high ones (\%); 2013, Hungary: 18.56, EUaverage: 23.82

Time turned to payments (days); 2013, Hungary: 42.33; EU-average: 50.76

Losses due to bad debts (per cent of the total income); 2013; Hungary: 4, EU-average 3.83

Risk-capital investments (per cent of the GDP); 2012, Hungary: 0.067, EU-average 0.04

Legal right index $(0-10) ; 2014$, Hungary: 7, EU-average: 6.82

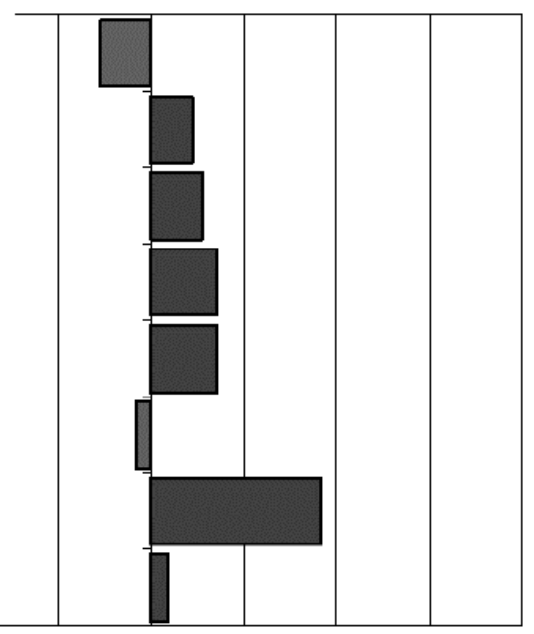

Remark: The data columns pointing to the right refer to performance beyond the union's average, while the ones pointing to the left refer to poorer performances.

Figure 5. Access to financial sources

Source : http://ec.europa.eu/enterprise/policies/sme/facts-figures-analysis/performancereview/files/countries-sheets/2014/hungary_hu.pdf (date of downloading: 02. 04. 2015) 
The gradual growth of the GDP-proportional risk-capital is a positive development in the past few years. Similarly to the other member states, there are only a few small and medium-sized enterprises having access to risk-capital, but the general conditions are something better in Hungary. The JEREMIE I and II programs may have improved the conditions (Joint European sources supporting micro, small and medium-sized enterprises) in the recent past that would have improved the situation in spite of the doubt about the efficiency of the execution (e. g. concerning the selection of the small and medium-sized enterprises).

In 2013 and the first quarter of 2014, some moderate results were achieved in this field by means of various interventions. First of all, a new credit program applying preferential interests was introduced. In the framework of the Growth Credit Program, the Hungarian National Bank grants funds to the commercial banks providing subsidised supports for the companies to facilitate the enhancement of their research and development and innovation capacities and the development their business environment. Secondly, in the framework of financing programs provided by EXIM Bank, by a newly introduced limit of credit, the small and medium-sized enterprises may obtain financial support to buy production equipment at preferential interest rates (EUR 600 million) to increase export.

\section{Growth Credit Program}

Since 2008, the volume of crediting of the small and medium-sized enterprises (exchange rate effects filtered out), although with some swings, was decreased gradually. The preferential conditions of the Growth Credit Program (the greatest advantages are the fixed interest rate and the long-term option) have been able to influence the willingness to credit and borrow significantly. Before the introduction of the Growth Credit Program, the small and mediumsized enterprise sector was in a more adverse position as compared to the ventures of other member states of the European Union.

The willingness of crediting and risk taking by the banks might depend on the conditions, how the redemption burden of the potential debtor will be formed in the future depending on the interest rate, the interest risk and possibly the exchange rate risks. This hypothesis presumes that the credits accessible under better conditions will stimulate the demand for credit on the side of the borrowers as well. Considering the fact that the Growth Credit Program offers longterm, fixed and low interest rate credits (interest rate $2.5 \%$ and maximum duration of 10 years) instead of the short-term market credits of higher and variable interest rates, it an be used to survey the real demand for credit and client risks as well [MNB- Növekedési Hitelprogram bemutatása, 2013].

The Growth Credit Program has brought decisive changes in the practice of crediting of the small and medium-sized enterprises (Figure 6.). 


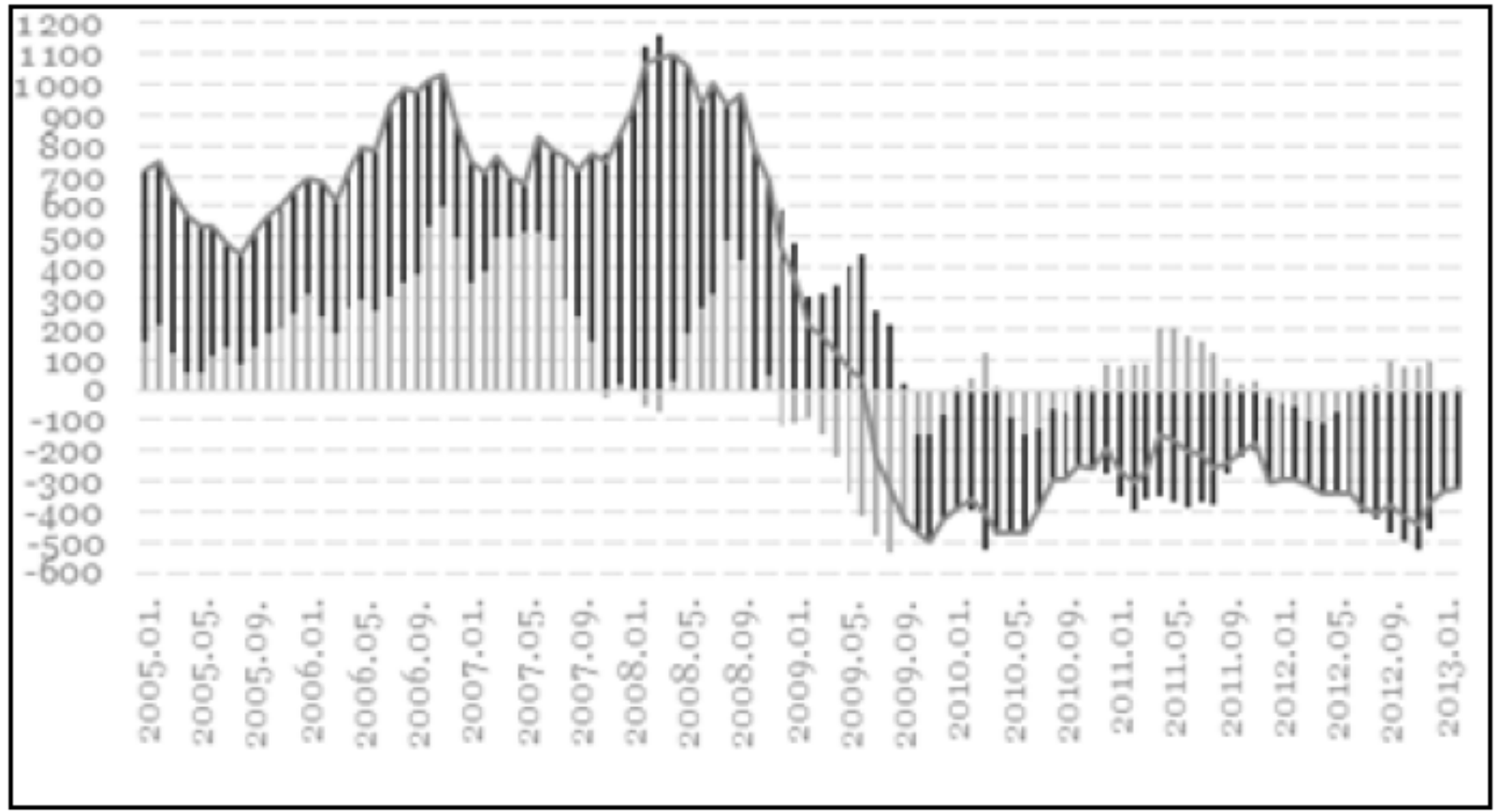

Figure 6. 12-month rolling net amount of company HUF and foreign currency credits laid out (HUF billion)

Source: MNB - Growth Credit Program information - portfolio.hu (date of downloading: 29. 04. 2013)

Pursuant to statistical data, trend-breaking took place in the crediting of companies, particularly the small and medium-sized enterprises. While earlier the assets shrunk by $4-6 \%$ a year, it stagnates since the third quarter of 2013 thanks mainly to the positive effects of the Growth Credit Program. Several company surveys proves that the stimulation of the crediting emerge on the side of the demand as well: a significant part of the companies participating in the credit program would not have taken credits on market basis or, if yes, in smaller amounts. The first pillar of the Growth Credit Program started in 2013 has produced a positive effect in the credit asset of the small and medium-sized enterprises in a very short time ( $3-5$ months). Thanks to this program, the net changes in the company credit asset in the entire crediting sector has approximated the amount of HUF 600 billion (Figure 7.) 


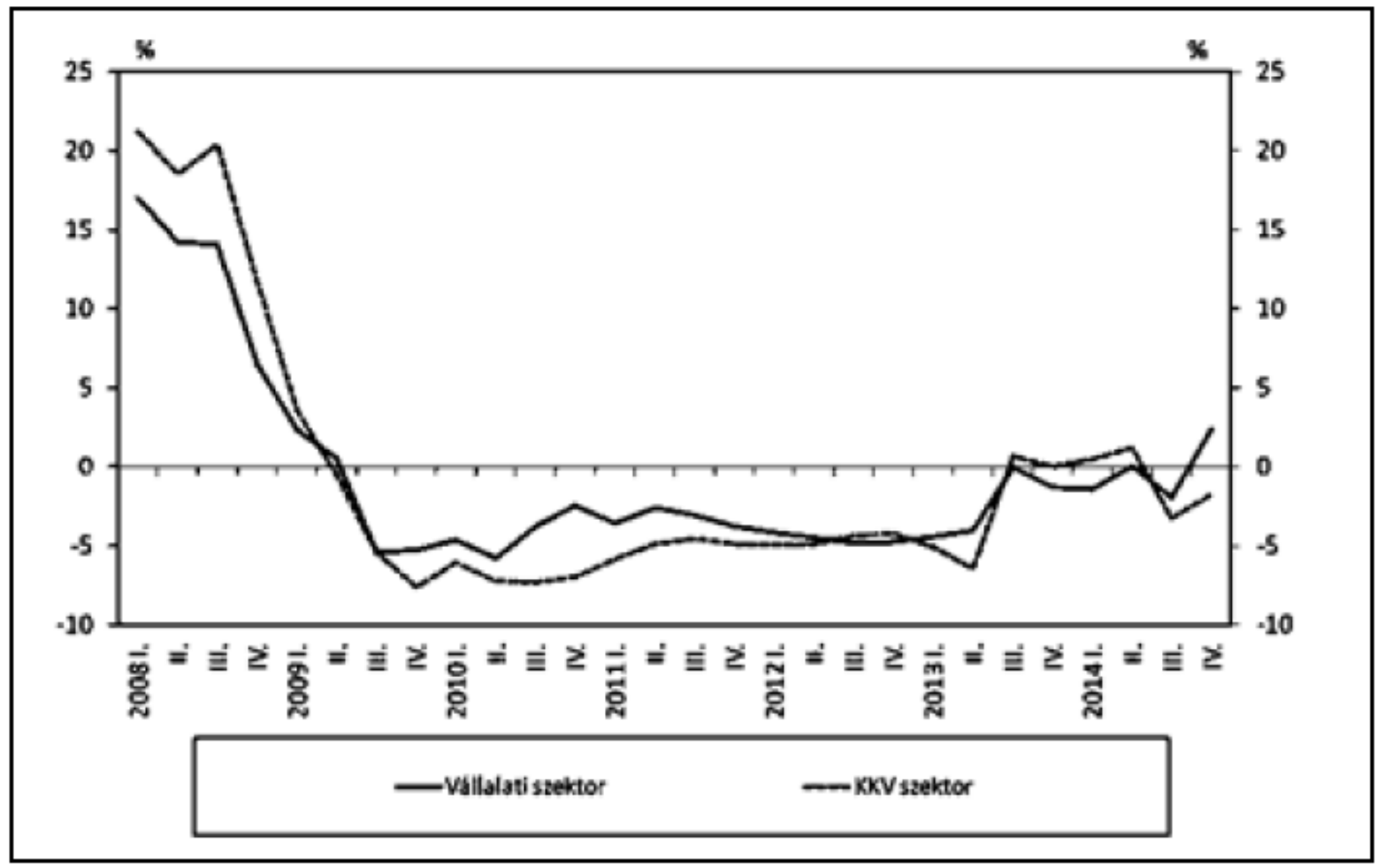

Figure 7. Rate of growth of the credit assets in the entire company and the small and medium-sized enterprise sectors

Source: http://www.mnb.hu/Kiadvanyok/hitelezesi-folyamatok/hitelezesi-folyamatok-2015marcius (date of downloading: 02.04. 2015)

In the primary questionnaire, we would like to highlight whether the fixed low interest rates did cause anchoring effect concerning the interest rates of the market credits and the properly long duration or did it improve the dialogue between the financing banks and the clients. It is important to emphasise that the goal of the Growth Credit Program is to stimulate the process of crediting in an interim period instead of replacing the market irrecoverably. The financial mediator system shall overtake control, the market crediting may become active in mediumterm and the growth of the economy may facilitate the demand for crediting.

\section{Challenges to be faced by the players of market financing}

The Hungarian credit market for the small and medium-sized enterprises is unbalanced for many years. Until 2008 it lived its golden age thanks to the low source costs, decreasing risk related costs and low expectations for yield. The activity of the capital market grew [Élö halott a hitelezés , 2013]. The structural problems arising in the 2000's were hidden behind the growth: the insufficiencies in the size-structure, capital intensity and innovative potentials. The uncertainties generated by the rapidly changing legal and accounting environments were less apparent yet. This trend was broken in 2008-2009, the credit/GDP rate fell dramatically and the downhill ride, disregarding some small variations, might be stopped today. The demand has returned partially, but the market offers on the side of the banks still lag behind. Following the shocks caused by the losses suffered and due to new kinds of uncertainties the costs of the market financing did not return yet to the low level experienced before the crisis. The bank sector struggles with the problems and makes various analyses (Table 3.) to satisfy the demands for yield of the owners and the markets; however, it is not sure whether the banks will be able to deliver the savings to the borrowers in the previous effective form [DIETZ, M. partner, 2012]. 
Table 3. Analysis of the market players by particular points

\begin{tabular}{|c|c|c|c|}
\hline & $\begin{array}{l}\text { Finance } \\
\text { institutions }\end{array}$ & KKV-enterprises & State \\
\hline \multirow{3}{*}{ UNDERSTANDING/TRUST } & $\begin{array}{l}\text { - Exact analysis of } \\
\text { the KKV structures }\end{array}$ & •Transparency & \multirow{3}{*}{$\begin{array}{l}\text {-Assuming } \\
\text { responsibility } \\
\text { mutually by } \\
\text { agreement }\end{array}$} \\
\hline & $\begin{array}{l}\text {-Understanding the } \\
\text { KKV life cycle }\end{array}$ & •Responsibility & \\
\hline & $\begin{array}{l}\text { - Exact } \\
\text { categorisation }\end{array}$ & •Collaboration & \\
\hline DIVERSIFICATION & $\begin{array}{l}\text { - Finding partners } \\
\text { in the international } \\
\text { markets } \\
\text {-Creating new, } \\
\text { custom-made } \\
\text { financing models }\end{array}$ & $\begin{array}{l}\text {-Direct access to } \\
\text { foreign financial } \\
\text { sources } \\
\text { - Redistribution of } \\
\text { the capital inside the } \\
\text { region } \\
\text { - Mutual capital } \\
\text { allocation }\end{array}$ & $\begin{array}{l}\text { - Combined } \\
\text { methods, proper } \\
\text { combination of } \\
\text { effective source } \\
\text { and capital } \\
\text { allocation tools }\end{array}$ \\
\hline \multirow{3}{*}{ INNOVATION } & $\begin{array}{l}\text {-Actual costs and } \\
\text { operation }\end{array}$ & $\begin{array}{l}\text {-Organisational } \\
\text { innovation }\end{array}$ & $\begin{array}{l}\text {-Constructive } \\
\text { regulation }\end{array}$ \\
\hline & $\begin{array}{l}\text {-Focusing on risk } \\
\text { correspondence }\end{array}$ & $\begin{array}{l}\text {-Proportional cash- } \\
\text { flow and capital } \\
\text { management }\end{array}$ & $\begin{array}{l}\text { Marker } \\
\text { stimulating } \\
\text { solutions }\end{array}$ \\
\hline & $\begin{array}{l}\text {-Introducing } \\
\text { dynamic pricing }\end{array}$ & & $\begin{array}{l}\cdot \text { Effective } \\
\text { warranty system }\end{array}$ \\
\hline
\end{tabular}

Source: own edition, 2015

\section{Summary, Conclusion possible answers to the challenges}

The intent of our paper was to analyse the actual economic position of and financing possibilities for the Hungarian micro, small and medium-sized enterprises. The consequences of the primary survey may provide answer to the question, what combination of the assumptions is operational and in what proportion could they result in the formation of more effective structures.

Solutions to abolish the unbalance in the crediting can be found inside and outside the bank sector, but the different problems discover different interdependencies. There are a huge differences between the possible individual outcomes:

- the capital can not reach the economy, the growth will sink,

- the state increases its economic activity, but such a capital or source allocation is much less effective than the market driven one, for this reason, it can stimulate the crediting provisionally,

- the shadow banking system tries to fill the gap (shadow banking),

- not the banks, but the individual investors finance each other (crow funding).

What the banks can do: execution of significant expansion in the traditional credit and investment markets, offering innovative, low price alternatives applying new and reliable assurances. They must significantly reduce the ROE and COE costs, execute additional consolidations and network reduction and look for external markets. Most of all, the banking 
market must be more innovative, the most important market must be recognised and the career demands must be satisfied. Furthermore, the fact that the real growth in the demand for credit can be reached, if the trust in the market will be restored and a stable economic vision will be shown to the enterprises by the banks, shall be considered as a central issue.

What the state can do: the effective bank capital allocation and the constructive regulatory tools shall optimally be combined in the system of stimulation: positive taxation system for the banks facilitating the crediting, effective system of institutions and warranties by means of interest rate balancing methods. Market stimulation systems to be provided directly for the banks or the banks and clients in combination shall be sought and applied in the required volume. Inspect the legal and accounting environment concerning the small and medium-sized enterprise sector and modify it as required by the stimulation of the economy.

What the small and medium-sized enterprise sector can do: beside the proportional cash flow and capital management, the most important factor is the improvement of transparency, responsibility and cooperation to be completed with the intensive development of the organisational innovation. However, the ventures are able to introduce innovations, if they are in possession of human capital as well. This can be done, if - beside governmental interventions - the economic organisation encourages the continuous training of their employees.

\section{References}

1. Béza D. and Csubák T. K. [2005] Kisvállalkozások pénzügyei. Small business financing, Budapest: Corvinus University of Budapest Small Business Development Centre. (written course material)

2. Csubák, T. K [2003]: Kis- és középvállalkozások finanszírozása Magyarországon, Doktori Értekezés, Budapesti Közgazdaságtudományi és Államigazgatási Egyetem

3. Dietz, M. [2012]: Crediting in Hungary, presentation of 17. May 2012. (McKinsey\&Company)

4. Élő halott hitelezés - Egy konferencia tanulságai (2013) www.portfolio.hu

5. KKV Évkönyv (2012): A kis- és középvállalkozások helyzete Magyarországon, KKV Évkönyv 2012, Budapest, 2012

6. Gyenge Balázs, Buresch János, Kozma Tímea (2013): How to Measure the Efficiency of Management Strategy in Organisational Structure. In: BYLOK F. at al (ed.): HUMAN CAPITAL AND CORPORATE RESPONSIBILITY. Czestochowa, Lengyelország Czestochowa: Politechniki Czestochowskiej, pp. 60-72.

7. European Comission [2014]: A partial and fragile recovery - Annual report on european SMEs 2013/2014. hely nélk. : European Union

8. Kállay, L., Kissné, E.K., Köhegyi, K and Maszlag, L. (2005) A kis- és középvállalkozások helyzete. Éves jelentés 2003/2004 (The situation of small and medium-sized enterprises. Annual report 2003/2004), Budapest : Ministry of Economy and Transport.

9. Kállay, L. (2012) KKV-szektor: versenyképesség, munkahelyteremtés, szerkezetátalakítás (SME sector: competitiveness, job creation, restructuring), Budapest: Corvinus University of Budapest Institute of Business Economics. (working paper)

10. Központi Statisztikai Hivatal

11. Hungarian Central Statistical Office (HCSO) FLASH SURVEY, (2014 NOVEMBER) A kis és középválalkozások jellemzői (Characteristics of small and medium businesses) Budapest: Hungarian Central Statistical Office 
12. MNB [2013]: Növekedési Hitelprogram bemutatása, http://www.mnb.hu/Root/Dokumentumtar/MNB/Kiadvanyok/szakmai_cikkek/hiteleze snhp/KKV_cikk_final_final.pdf

13. Nemzetgazdasági - Minisztérium, www.kormany.hu/hu/nemzetgazdasagiminiszterium/videok/a-magyar-kkv-k-ketmillio-embernek-biztositanak-munkahelyet

14. Szerb, L. (2008) 'A haza kis- és középvállalkozások fejlödését és növekedését befolyásoló tényezők a 2000-as évek közepén' (Factors influencing SME growth and development in Hungary in the middle of the 2000s), Vállalkozás Innováció (Business Innovation) vol. 2, no. 2, 2008 second quarter

15. Walter, GY. [2014] Vállalatfinanszírozás a gyakorlatban (Business financing in practice), Budapest: Alinea Kiadó 